\title{
Fen bilgisi öğretmeni eğitiminde yerleşke bahçesinin öğrenme ortamı olarak kullanılması
}

\author{
Sibel TELLI $\mathbf{1}^{*}$ \\ ${ }^{1}$ Çanakkale Onsekiz Mart Üniversitesi; Eğitim Fakültesi Matematik ve Fen Bilimleri Eğitimi Bölümü \\ Fen Bilgisi Eğitimi Anabilim Dalı Çanakkale, Türkiye \\ Gelis Tarihi (Received Date): 04.02.2021 \\ Kabul Tarihi (Accepted Date): 24.06.2021
}

$\ddot{\mathbf{O} z}$

Bahçe temelli eğitim, örgün ve yaygın ögrenme ortamlarının bir araya getirilmesinde önemli rol oynamakta ve farkl eğitim düzeylerinde uygulanmaktadır. Ĕgitimde güncel yaklaşımlarla, ögretmenlerin farklı ögrenme ortamlarında birden çok öğretim tekniği kullanmaları beklenmektedir. Ancak, ĕğitim araştırmaları, öğretmen ĕgitimi programlarının hala ăgırlıklı olarak sınıf içi ortamlara odaklandı̆̆ını ve ögretmenlerin ögrencilerini sınıf dışına çıkarmak için hazır olmadıklarını veya kendilerini hazırlıklı hissetmediklerini göstermektedir. Bir durum araştırması olan bu çalışmada, fen bilgisi ögretmen adaylarını okul bahçelerinin eğitimsel kullanımıyla tanıştırmak, alan öğretimi becerilerini geliştirmek ve onlara sınıf dışı öğrenme ortamlarında güven kazandırmak amaçlanmıştır. Çalışma 2014-2015 akademik yılında Bahar döneminde 38 fen bilgisi ögretmen adayının katılımıyla bir devlet üniversitesinde yürütülmüştür. Ders araştırmaları modeli takip edilerek hazırlanan ders, mobil teknoloji ile zenginleştirilmiş sinıf dışı ögrenme ortamında (yerleşke bahçesi) üç fen bilgisi ögretmen adayı tarafindan verilmiştir. Öğretmen adayları, bitkilerin bilimsel isminin kullanmasında farkındalıklarının olduğunu ancak kendilerini yeterli hissetmediklerini belirtmişlerdir. Sonuçlar, ders araştırmaları modelinin öğretmen adaylarının mesleki yeterliliklerine ve alan bilgilerine katkısını göstermiştir. Çalışma sonuçlarının, fen bilgisi öğretmen adaylarının sınıf dışı ögrenme ortamlarında alan ögretimi ve genel mesleki yeterliliklerine katkı sağlaması beklenmektedir.

Anahtar kelimeler: Biyoloji eğitimi, ders araştırmaları, ögretmen adayı eğitimi, sınıf dışı ögrenme ortamlarl

\footnotetext{
*Sibel TELLİ, sibeltelli@ comu.edu.tr, http://orcid.org/ 0000-0002-0763-217X

Bu çalışmanın ilk şekli 27-29 Nisan 2017 tarihlerinde düzenlenen 7th International Conference on Research in Education - ICRE, Çanakkale Onsekiz Mart Üniversitesi, Çanakkale, Türkiye kongresi’nde, ikinci şekli 03-04 Haziran 2020 tarihlerinde düzenlenen 10th International LUMAT Symposium: Research and Practice in Math, Science and Technology Education (LUMAT), Aalto University, Espoo, Finland Kongresi'nde sunulmuştur.
} 


\title{
To use of campus garden as a learning environment in the preservice science teacher education
}

\begin{abstract}
Garden-based teaching plays an important role in bringing the formal and informal learning environments together and is applied at different educational levels. Teachers are expected to use multiple teaching technique in different learning environments align with the contemporary educational approaches. However, educational research shows that teacher education programs still mainly focus on the classrooms and teachers are not prepared or do not feel prepared to take their students out of the classroom. This case study aimed to introduce the educational use of school gardens to the pre-service science teachers and to improve their subject knowledge, the subject teaching competency and provide the confidence of teaching outside the classroom, school garden. The study was conducted in a public university with the participation of 38 pre-service science teachers in the 2014-2015 academic year. Three preservice science teachers prepared the lecture based on the "lesson study" model and gave the lecture to their classmates in an outdoor learning environment (campus garden) enriched with the mobile technology. The preservice teachers stated that they are aware of the importance of using the scientific name of plants, but they do not feel themselves competent. The results show that the lesson study model can contribute to the preservice teachers' subject knowledge and professional competencies. The results of the study are expected to contribute to the preservice science teachers' awareness of the outdoor learning environments, support the practice-based subject teaching and their general professional competencies.
\end{abstract}

Keywords: Biology education, lesson study, outdoor learning environment, pre-service teacher education.

\section{Giriş}

Araştırmalar, öğretmenlerin mesleğin ilk yıllarında karşılaştıkları zorluklarla mesleki gelişimleri, verimlilikleri ve meslekten ayrılmaları arasında bağlantı olduğunu göstermiştir [1-5]. Bununla birlikte öğretmen adaylarına dönüt aldıkları destek programlarının hem mesleki devamlılıklarına [6-9] hem de takip ettikleri gelişim programlarından aldıkları verimde olumlu etkilisi olduğu belirlenmiştir [10]. Çalışmalar da, uygulamanın öğretmenlik mesleğindeki önemini sürekli vurgulanmıştır [11-14]. Öğrenmenin, okul ve sınıfla sınırlı kalamayacağı gerçeği $[15,16]$ sınıf dışı ortamlarda da eğitimin devam etmesi $[17,18]$, öğretmenlerin bu ortamlarda da uygulama deneyimlerinin olmasını gerektirmiştir. Ancak, öğretmen yetiştirme programları sınıf içi öğrenme ortamlarına yoğunlaşmaya devam etmiş [19-21], öğretmenler öğrencilerini sınıf dışına çıkartmada çeşitli nedenlerle kendilerini yeterli hissetmediklerini belirtmişlerdir $[22,23]$. Araştırmalar, sınıf içi ve dışı öğrenme ortamları arasında bağlantının kurulması [24], öğretmen yetiştirme sürecinden başlayarak öğretmenlere bu konuda mesleki yeterliliklerinin kazandırılması gerektiğini göstermiştir [25]. Ancak, sınıf dışında öğretmen adaylarıyla yapılan uygulama örnekleri sınırlıdır ve genelde de katılımcı durumundadirlar [26, 27]. 


\subsection{Okul bahçesi}

Sınıf içi ve dışı öğrenme ortamlarının sınır çizgisinde olan okul bahçeleriyle ilgili çalışmalar 1900 yıllarına kadar uzanmaktadır [28, 29]. Okul bahçelerinde, peyzaj ve mimari özellikleri [30-32], öğrenci sağlığı ve beslenme alışkanlıklarının edindirilmesindeki önemi [33-36], okul içindeki zamanın verimli değerlendirilmesi ve çevre eğitimi [37], öğrenci kazanımları [38, 39] gibi farklı konularda çalışmalar bulunmaktadır. Okul bahçeleri disiplinler arası çalışmalara uygunluğu ve öğretmen yetiştirmede uygulama ve teorinin, sınıf içi ve dışı öğrenme ortamlarının bir araya getirildiği "açık sınıf" olarak öğretim ve eğitim fonksiyonu taşıyabilirler [40]. Ancak, okullardaki günlük aktivitelerin merkezi olan okul bahçeleri, öğretmen yetiştirmede doğrudan eğitim ve uygulama alanı olarak kullanılmadığı [41] ve ülkemizde öğretmen eğitimiyle ve öğretmenlik performansı arasındaki ilişkiyi irdeleyen araştırmaların da fazla yapılmadı̆̆ amaçlı kullanımı için yönlendirme almaları gerektiği de görülmüştür [43, 44].

\subsection{Ders araştırmaları}

Japonya'da öğretmenlik uygulamalarında esas olan "Ders Araştırmaları" modeli [45-48], öğretmenlerin belirledikleri amaç doğrultusunda işbirliği içinde hazırlıklarını değerlendirdikleri bir mesleki gelişim programı olarak kabul görmüştür [49-54]. Japonya dışındaki ders araştırmaları çalışmalarında ise modelde yapısal, sosyal veya kültürel farklılıklara atfedilebilecek uyarlamalar gerektiği belirtilmiştir $[55,56]$. Model, genel olarak, (I) hedef ve araştırma sorusunun seçilmesi (II) planlanma (III) dersin işlenmesi veya gözlemlenmesi (VI) hedef ve öğrenci öğrenmesine odaklanan ders sonrası tartışma (V) dersin gözden geçirilmesi ve tekrarlama (IV) deneyimleri yansıtma, edinilen bilgilerin paylaşılmasını içeren, ardışık bir döngü şeklinde verilmiştir [54] (Bkz. Tablo 1). Bu çalışmada takip edilen model, öğrenim materyalinin (Kyouzai kenkyuu) "Konum Bul” geliştirilmesi nedeniyle Japonya' da uygulanan modele yakındır [55].

Araştırmalar (biyoloji) alan bilgisi ve çevre eğitiminde özellikle uygulamaya dayalı çalışmaların öğretmen eğitimindeki önemini göstermiştir [56, 57]. Bununla birlikte, öğretmen adaylarının mesleki yeterliklerini iyileştirmek için dışsal ve içsel geri bildirimin etkili olduğunu belirtmiştir. Her iki geribildirim şeklinin, öğretmen adaylarının, öğretim materyalleri tasarlama, öz değerlendirme ve düzenleme kalitesini artırabileceği gösterilmiştir [58].

Öğretmenlerin genel ve alan mesleki yeterliliklerinin [59, 60] desteklenmesi ve mesleğe hazırlanmada "ders araştırmaları" çalışmalarının etkili olduğu görülmüşs [61-63, 51, 53] ve yansıtma, işbirliği, gözlem ve motivasyonu teşvik ettiği bildirilmiştir [50, 64-66]. Ülkemizdeki öğretmen ve öğretmen adaylarının konuyla ilgili görüşlerine yönelik çalışmalarda, "ders araştırma" modelinin öğretmenlik mesleğine katkısına ve mesleki gelişim açısından önemine dikkat çekilmiştir [67, 61, 68]. Ancak, modelin öğretmen eğitimindeki uygulamalı örnekleri sınırlıdır ve genel olarak sınıf içi öğrenme ortamlarına yöneliktir [69-71].

Bu çalışmada, fen bilgisi öğretmen adaylarının hazırladıkları dersi, sınıf dışı ortamda (yerleşke bahçesi) dönem arkadaşlarına aktarmaları paylaşılmıştır. Yukarıda belirtilen kuramsal çerçevede, bu çalışmada ders araştırmaları modeli takip edilerek hazırlanan dersin, öğretmen adaylarının sınıf dışı öğrenme ortamlarında mesleki kazanımlarına etkisini incelemek amacıyla aşağıdaki sorulara cevap aranmıştır. 
1. Sınıf dışında uygulamaya dayalı dersin öğretiminde ders araştırmalarının, fen öğretmeni adaylarının mesleki becerilerine ve biyoloji alan bilgilerine katkısı nedir?

2. Fen bilgisi öğretmen adayları ders araştırmalarının yararlılığını ve uygulanabilirliğini nasıl değerlendiriyor?

\section{Yöntem}

\subsection{Araştırmanın deseni}

Durum çalışması, bir kişi, bir grup, bir kurum veya kuruluş ve vakayla ilgili sınırlı bir sistemin çoklu veri toplanarak detaylı incelenmesine yönelik bir yaklaşımdır [72, 73]. Bu çalışmada, fen bilgisi öğretmen adaylarınca, ders araştırması modeline göre hazırlanan dersin, yerleşke bahçesinde dönem arkadaşlarına aktarmaları, bütüncül tek durum deseni olarak tasarlanmıştır.

\subsection{Katilimcilar}

Çalışma 2014-2015 akademik yılında Bahar döneminde bir devlet üniversitesinde FEN136 Genel Biyoloji II dersi kapsamında yaşları 20 ile 23 arasında değișen, 38 fen bilgisi öğretmen adayının gönüllü katılımıyla tamamlanmıştır. Katılımcılar, sınıf içinde farklı derslerde sunum yapma veya bireysel olarak ders verme deneyimleri olduğunu belirtmişlerdir.

\subsection{Veri toplama araçları}

Öğretim materyali, görüşme formları, bir adet portfolyo kullanılarak çalışmanın verileri toplanmıştır. Dersin hazırlanması süresince öğretmen adaylarından saha notları tutmaları istenmiştir. Dışsal ve içsel geri bildirim (bireysel ve grup seviyesinde) formları öğretmen adaylarının mesleki gelişimine destek olmak amacıyla kullanılmıştır.

Öğretim materyali (Kart-01 ve Kart-02, Bkz. Hafta 06) üç fen bilgisi öğretmen aday1 tarafından, yerleşkede çalışma yapmak istedikleri konumda, belirledikleri on farklı bitki türüyle oluşturulmuştur. Materyal gelişim süreci, araştırmacı (Öğretmenlik meslek deneyimi 15 yıl üzerinde olan alan eğitimcisidir.) ve biyolojide doktora derecesine sahip iki bitki biyoloğu tarafından takip edilmiştir. Çalışmada, görüşme A, B ve C olmak üzere üç farklı görüşme yapılmıştır (Bkz. Tablo 1). Görüşme-A (bireysel), Görüşme-B (grup) yapılandırılmış formda 10'ar dakika ve Görüşme-C (grup) serbest formda zaman sınırlaması olmadan düzenlenmiştir. Haftalık görüşmelerde (A) dersi hazırlayan üç öğretmen adayına bireysel olarak ders araştırmaları modeline göre ders planı ve materyalin geliştirilmesi, grup olarak uyumları ve görev dağılımlarıyla ilgili sorular yöneltilerek, dersin hazırlık süreci izlenmiştir. Bu sorular " Bu haftaki çalışmanıza 100 üzerinden kaç puan verirsiniz?” (A-Soru-1), "Bu hafta ki çalışmanız ve geçen hafta ki çalışmanızı karşılaştırdığınızda, sizce çalışmanızın hangi kısımları ilerledi ?” (A-Soru2), "Kendinizi bu aşamada, dersi sınıf dışında tek başınıza verecek yeterlilikte hissediyor musunuz?" (A-Soru-3), "Dersi bu aşamada, tek veya şu anki grup arkadaşlarınızla mı vermek istersiniz?" (A-Soru-4), "Ekip çalışmasında sizce önemli olan nedir?" (A-Soru5) şeklindedir. Uygulama dersi sonunda yapılan görüşmede (B), sekiz katılımcı gruba (toplam 38 öğretmen adayı, Bkz. Hafta 8) verilen dersin değerlendirmesine yönelik sorular sorulmuştur. Cevaplarda önem sırası istenmeden, "Bu çalışmada öğrenme açısından verimli bulduğunuz üç şey nedir?" (B-Soru-1), "Bu çalışmada öğrenme açısından geliştirilmesi gerektiğini düşündüğ̈̈nüz üç şey nedir?" (B-Soru-2) sorular1 yöneltilmiştir. Görüşme sonunda, üç öğretmen adayı tarafından hazırlanan portfolyo sekiz grup tarafından incelenmiştir. Gruplardan ağırlıklı rubrik örneğine göre 
portfolyoyu puanlandırmaları istenmiştir (Bkz., Ek 1). Ders sonunda 38 katılımeı fen bilgisi öğretmen adayıyla yapılan bireysel genel görüşmede (C), dersin tekrarlanması durumu için önerileri alınmıştır. Sonrasında, öz değerlendirme ve kendi grubu için performans puanlaması yapmaları istenmiştir. Sekiz grup tarafından incelenen portfolio, üç fen bilgisi öğretmen adayının ders hazırlıklarını içermektedir. Bunlar, ders planı, haftalık güncellemeler, eğitim materyalleri [Konum Bul, bilgi kartları (Kart-01), kurutulmuş yaprak örnekleri ve çizimleri (Kart-02), bitki konumları, kroki] ve dersin hazırlanması süresince öğretmen adaylarının saha notlarıdır.

\section{4. Öğretim ve veri toplama süreci}

2014-2015 Akademik yılı Bahar dönemi ders izlencesi paylaş1lırken, gönüllük esasına dayalı grup çalışmaları, konu başlıkları, amaçlar ve etik düzenleme hakkında bilgi verilmiştir. Uygulama için öğretmen adaylarının gün içinde en çok zaman geçirdiği dış mekân olan Çanakkale Onsekiz Mart Üniversitesi (ÇOMÜ) Eğitim Fakültesi yerleşkesi önerilmiştir. Çalışmanın sekiz hafta ${ }^{1}$ için planlandığı (Tablo 1) ancak hazırlık sürecine bağlı olarak on hafta şeklinde güncellenebileceği ve paylaşılan başlıklar dışında öğretmen adaylarının öneri getirebilecekleri belirtilmiştir. İlgilenen öğretmen adaylarının grup oluşturarak bir hafta içinde iletişim kurmaları istenmiştir.

HAFTA-01 Gönüllü gruplarla yapılan ilk toplantıda, taslak olarak düzenlenen haftalık çalışma takvimi ve dersteki açıklamalar hatırlatılmıştır. Araştırma dersi [45] ve portfolyo çalışması hakkında bilgi verilmiştir [74] (Ek 1). Çalışma yapılacak zaman ve haftalık bireysel görüşmelerin (Görüşme-A) öğretmen adaylarının ders programına göre yapılması kararlaştırılmıştır.

HAFTA-02 Öğrenci grubuyla yerleşke bahçesi gezilmiştir ${ }^{2}$. Yerleşkenin çalışmadan beklenen çıktılara ve uygulamayı yapmak isteyen öğretmen adaylarının ön hazırlıklarına uygun olabilecek alanları incelenmiştir. Öğretmen adayları C Blok arkasında "Arka Bahçe" ve A Blok önünde "Ön Bahçe" olarak isimlendirilen iki kısmın kendi çalışmalarına uygun olabileceği belirtmiştir (Görsel 1a,b).

HAFTA-03 "Arka Bahçe" ve "Ön Bahçe” de ki bitki çeşitliliğini incelenerek, çalışma taslaklarını oluşturulmuş ve krokiler hazırlanmıştır.

HAFTA-04- Öğretmen adaylarıyla "Arka Bahçe" ve "Ön Bahçe” gezilerek, çalışma planları ve ön hazırlıkları incelenmiştir. "Arka Bahçe" ye göre daha küçük olması ve bitki çeşitliliği göz önünde bulundurularak, etkinliğin ve dersinin "Ön Bahçe" "de

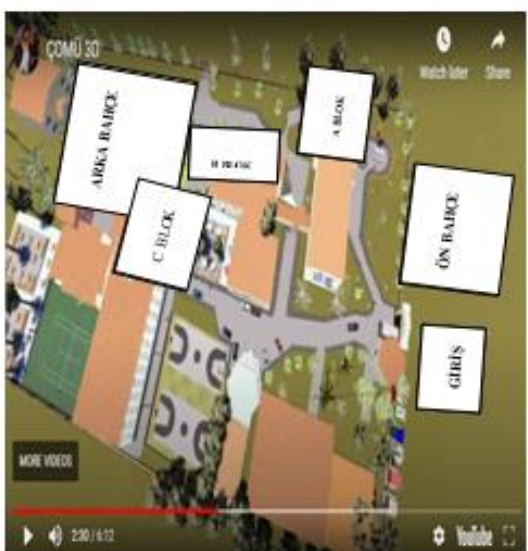

Görsella-Yerleşkeye genel bakış (2.30 dk., 「751)

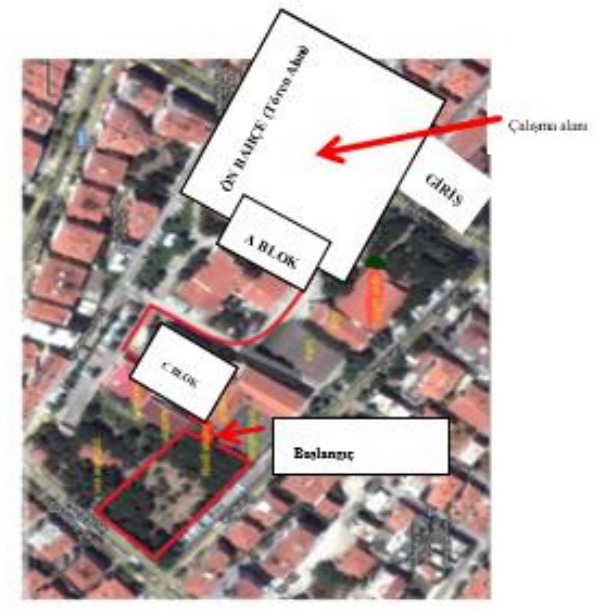

Görsellb-Ders güzergâhı (Google map, 2015) 
yapılması kararlaştırılmıştır. Sonrasında, derse başlarken yapılacak olan yerleşke turu güzergâhı belirlenmiştir (Görsel 1a, b).

HAFTA-05 "Konum Bul" etkinliği için 10 bitki türü belirlemek amaciyla, "Ön Bahçe" de ki bitki çeşitliliğine yoğunlaşılmıştır (Görsel 2a-d). Uygulama dersindeki sınıf hareketliliği (bilgi verme, toplanma noktası, kartları eşleştirme) tasarlanmıştır, istasyon yerleri ve zaman yönetimi ders planına eklenmiştir.

HAFTA-06 Öğretmen adaylarının çalışma için önerdikleri 10 farklı bitki türü [Olea europaea (Zeytin) Larix kaemferi (Karaçam), Eugenia polyantha (Defne), Trachicarpus fortunei (Kendir Palmiyesi), Juniperus sabina (Sabina ard1c1), Thuja occidentalis (Bat1 mazısı), Pinus sylvestris (Sarı Çam), Berberis thunbergii (Kadın tuzluğu), Chamaecyparis lawsoniana (Lawson yalanc1 servisi); Lawson's Cypress; Larix kaempferi (Japon Melezi)] (Bkz. Fotoğraf 1) hakkında görüşülmüştür. Seçilen bitkilerin yaprak örnekleri, mevcut durumu ve konum özellikleri incelenmiştir. Bitki türlerinin belirlenmesinde faydalanılabilecek kaynaklar ve bilgisayar uygulama program örnekleri paylaşılmıştır. Öğretmen adayları alan yazı incelemesine yönlendirilmiştir ${ }^{3}$. Yaprak kurutma ve saklama konusunda ön bilgi verilmiştir. Biyolojik çizim örnekleri ve kaynaklar paylaşılmıştır ${ }^{4}$.

Planlanan güzergâh ve zaman yönetimi, belirlenen bitki çeşitliliğine göre güncellenmiştir. Belirlenen her bitki için (Fotoğraf 1), genel özellikleri, bilimsel ve günlük isimlendirmeleri, besin ve tıbbı kullanımı, endemik önemi, farklı coğrafyalarda nasıl kullanıldığ1 ve tanındığı, sınıflandırma bilgisi, hortikültür değeri hakkında bilgiler içeren Kart-01 düzenlenmiştir. Yaprak örneği ve bu örneğin çizimini içeren Kart-02 hazırlanmıştır. Kartlardaki bilgilere dayanarak "Konum Bul" etkinliği düzenlenmiştir. Etkinliğin amacı, özellikleri verilen bitkinin konumunu bulmaktır. Kart-01 ve Kart02'nin hazırlanmasına başlanmıştır.
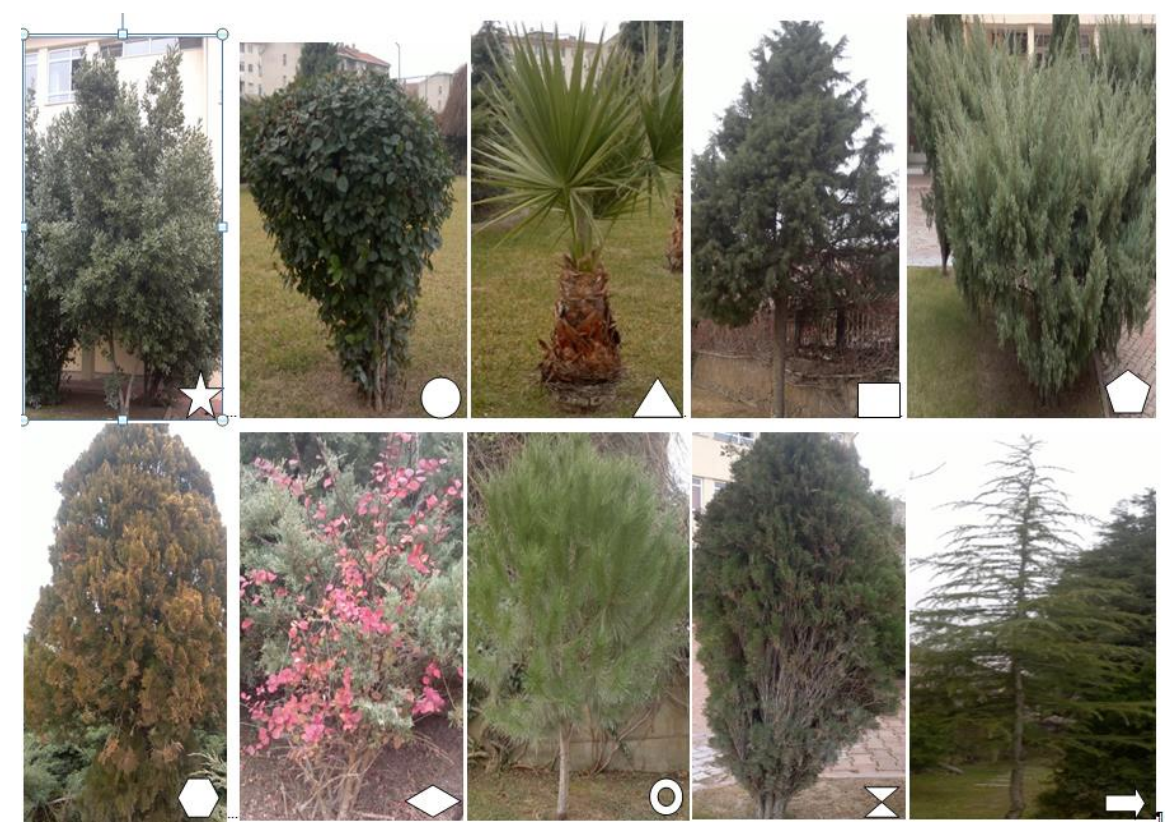

Fotoğraf 1. "Ön Bahçe" de çalışma için seçilen bitkiler, konumları ve kullanılan işaretleme (Bkz. Şekil 1, 2015) 
HAFTA-07 Belirlenen Olea europaea, Eugenia polyantha, Trachicarpus fortunei, Juniperus sabina, Thuja occidentalis, Pinus sylvestris, Berberis thunbergii, Chamaecyparis lawsoniana, Lawson's Cypress için hazırlanan bilgi kartları (Kart-01) incelenmiştir. Kurutulmaya başlanan yaprak örnekleri ve çizimlerine (Kart-02) dönüt verilmiştir. Bitkilerin "Ön Bahçe" de konumları krokide kontrol edilmiştir (Fotoğraf 1, Şekil 1). Bu aşamada, iki bitki biyoloğu akademisyenden bitkiler ve kartlarla ilgili dönüt alınmıştır. Öneriler doğrultusunda kartlarda düzenlemeler yapılmıştır.

Dersin, yerleşke bahçesindeki güzergâhı, açıklama noktaları, bu noktalardaki konuşma içerikleriyle birlikte provası 75 dakika sürmüştür. Ders için verilen süre (60 dakika) bu süreden kısa olduğu için dersin başında yapılacak olan yerleşke turundaki iki noktadaki açıklamalar dersten çıkarılmıştır (Görsel 1b). Yenilenen provada, ders 55 dakika' da tamamlanmıştır. 


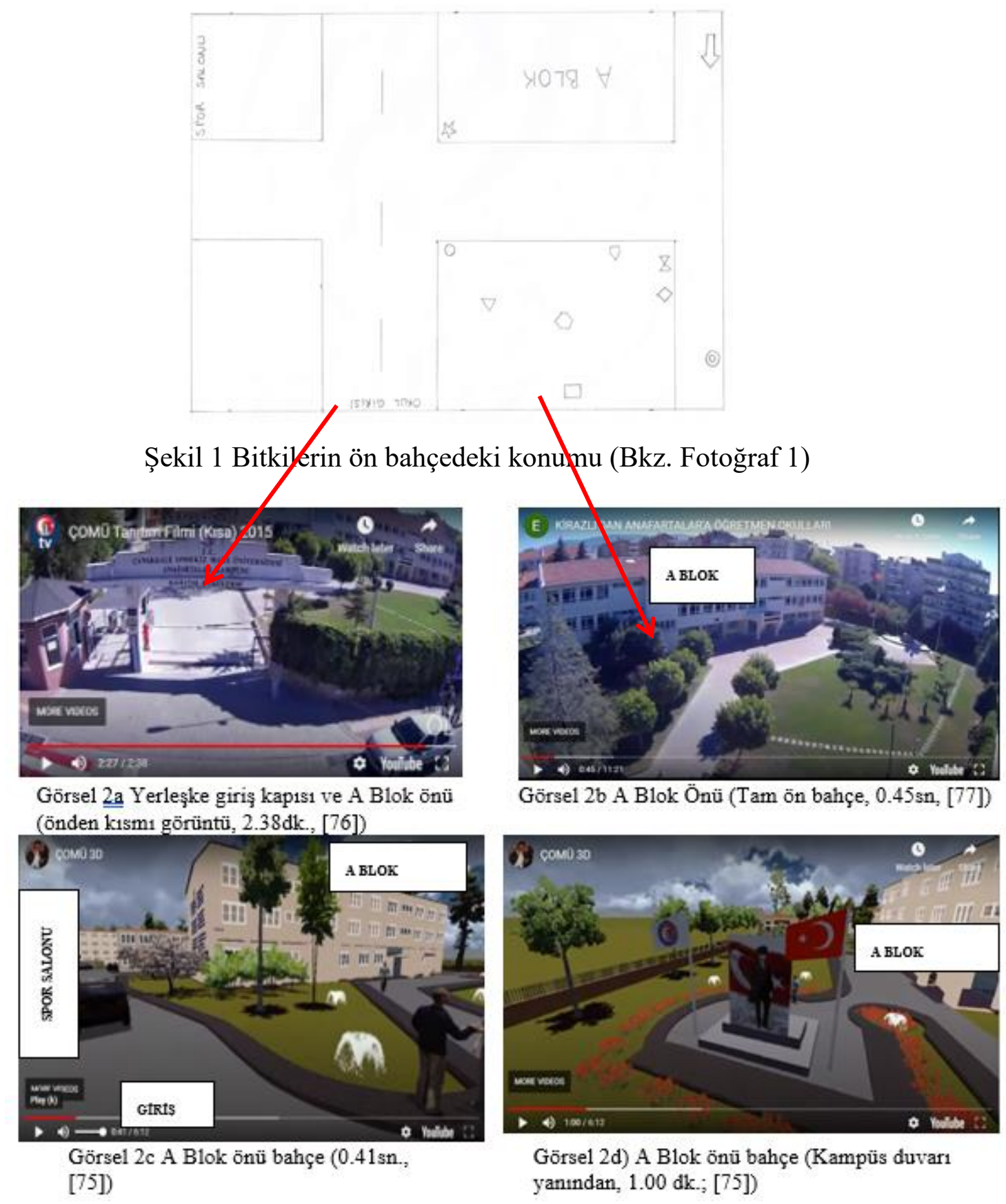

HAFTA-08 Öğretmen adayları, hazırlıklarını hafta içinde gözden geçirmeye devam ederek, provalarını tekrarlamışlardır. Ders günü, çalışma için katılımcılardan gruplar oluşturması istenmiştir. Katılımcı sayısına göre, 4 kişiden oluşan 5 grup $(4 \times 5=20)$ ve 5 kişiden oluşan 3 grup $(5 \times 3=15)$ olmak üzere 8 grup oluşturulmuştur $(20+15+3$ ders veren öğretmen adayı, toplam 38 katılımcı).

Yerleşkeye ve bitki çeşitliliğine genel bakışla derse başlanmıştır. Tur "Arka Bahçe" den başlayıp, giriş kapısına doğru ilerleyerek "Ön Bahçe" de tamamlanmıştır (4. Hafta, Görsel1b, Bkz. [75]. Planlanan konum ve istasyonlarda bilgiler paylaşılmıştır. Etkinlik ve materyal hakkında bilgi verilmiştir. Gruplar konumunu bulduğunu düşündügü bitkiyi, kendilerine verilen bahçe krokisinde işaretleyerek "Ön Bahçe" deki turlarını 
tamamlamışlardır (Görsel 2a-d). Toplanma noktası olarak belirlenen istasyona dönülmüştür. $\mathrm{Bu}$ süreçte gruplar arasında bilgi alışverişi olmamıştır. İstasyonda, dersi veren üç fen bilgisi öğretmen aday1, Kart-01'de verilen bilgilere yönelik hatırlatma sorularıyla başlamışlardır. "Akdeniz ülkelerinde süs bitkisi olarak yetiştirilen, tropikal ülkelerde ekonomik öneme sahip olan bitki hangisidir?"(Cevap: Cocos nucifera), "Sizinle paylaşılan bilgilerden hangisi size ilginç geldi?", "Çalışmadan önce hangi bitkiyi yerleşkede fark etmiştiniz?", "Yerleşkede ilk kez bu çalışmada fark ettiğiniz bitki var $m \imath$ ?" soruları yöneltilmiştir.

Hatırlatma sorularından sonra, gruplar işaretledikleri konumları paylaşmıştır. Sonrasında, bitkinin doğru konumu verilmiştir (Şekil 1). Bu işlem her bitki için tekrarlanmıştır.

Derse, sekiz grupla yapılan yapılandırılmış formda düzenlenen görüşmeyle (B) devam edilmiştir. Kullanılan kaynakça ${ }^{3,4}$ öğretmen adaylarıyla paylaşılmıştır.

Son olarak, serbest formda genel değerlendirme görüşmesi (C) yapıllmıştır. Portfolyo, rubrike (Ek 1) göre puanlandırılmıştır.

Tablo 1 Çalışma Takvimi

\begin{tabular}{|c|c|c|}
\hline Hafta & Çalışma ve uygulanan ölçüm & $\begin{array}{l}\text { Ders araştırmaları modeliyle ilgili } \\
\text { kısım }[55,54]\end{array}$ \\
\hline 00 & Çalışma konularının önerilmesi & $\begin{array}{l}\text { 0- düşünce ve fikirleri paylaşılması } \\
\text { I- öğretmenlik uygulamasından bir } \\
\text { soru veya sorunun paylaşılması }\end{array}$ \\
\hline 01. & $\begin{array}{l}\text { Çalışma grubuyla toplantı ve } \\
\text { bilgilendirme } \\
\text { Çalışma detayları ve } \\
\text { takvimleme }\end{array}$ & $\begin{array}{l}\text { I- öğretmenlik uygulamasından bir } \\
\text { soru veya sorunun paylaşılması } \\
\text { II- hedeflerinin tanımlanması }\end{array}$ \\
\hline 02. & $\begin{array}{l}\text { Yerleşke bahçesinin gezilmesi } \\
\text { Çalışma alanı için görüş } \\
\text { alışverişi } \\
\text { GÖRÜŞME A-01 }\end{array}$ & $\begin{array}{l}\text { III- verileri / yayınları / ders } \\
\text { materyallerini incelenmesi ve } \\
\text { bilginin paylaşılması }\end{array}$ \\
\hline 03. & $\begin{array}{l}\text { Yerleşke bahçesinde bitki } \\
\text { çeşitliliğinin incelenmesi } \\
\text { Çalışma taslakları ve krokilerin } \\
\text { oluşturulması } \\
\text { GÖRÜŞME A-02 }\end{array}$ & $\begin{array}{l}\text { III- verileri / yayınları / ders } \\
\text { materyallerini incelenmesi ve } \\
\text { bilginin paylaşılması }\end{array}$ \\
\hline 04. & $\begin{array}{l}\text { Çalışma alanının belirlenmesi } \\
\text { Ders güzergâhının } \\
\text { oluşturulması } \\
\text { GÖRÜŞME A-03 }\end{array}$ & $\begin{array}{l}\text { IV- Dersin tasarlanması (gözlem } \\
\text { formları dahil) ve ders planının } \\
\text { yazılması }\end{array}$ \\
\hline
\end{tabular}


Tablo 1 Çalışma Takvimi (devamı)

05.

Ön Bahçe bitki çeşitliliğinin
incelenmesi,
bitkilerin belirlenmesi
Ders içindeki istasyonların
belirlenmesi
Ders provası (ilk prova)
GÖRÜŞME A-04

06.

07.

08

\author{
Belirlenen 10 bitki türüyle ilgili \\ ön hazırlıkların gözden \\ geçirilmesi \\ Çalışmayla ilgili kaynakların \\ paylaşılması, \\ ara provalar \\ GÖRÜŞME A-05
}

provası

(son prova)

GÖRÜŞME A-06
V- Ders için, canlı gözlem ve veri toplanmas1

VI- Akademik görüş alışverişi ve yansitma

VI- Akademik görüş alışverişi ve yansitma
VII V ve VI öğelerini tekrarlanması ve ardindan son yansitma

\author{
Dersin işlenmesi \\ GÖRÜŞME A-07 \\ GÖRÜŞME B \\ (Genel değerlendirme, grup ve \\ bireysel öz değerlendirme) \\ GÖRÜŞME C \\ (Derse katılan fen bilgisi \\ öğretmen adaylarıyla yapılan \\ grup görüşmeleri) \\ Performans puanlamas1 \\ Portfolyo değerlendirme (Ek 1)
}

Ders

(shihan jvugyou)

VIII- Sonuçları ders çalışma ekibi dışındaki kişilerle paylaşılması

(bu çalışmada, sınıf arkadaşları)

\title{
2.5. Verilerin analizi
}

Veriler, "Konum Bul” etkinliğinden, yapılandırılmış (A, B) ve genel serbest görüşme (C) formlarından, bir adet portfolyo değerlendirmesinden, saha notlarından, yansitmalardan ve performans değerlendirmesinden elde edilmiştir.

"Konum Bul" etkinliği 10 farklı bitki için 15 dakika olarak planlanmıştır ve iki aşamada değerlendirilmiştir.

(1) Bitki konumu bulma: Konumu doğru belirlenen her bitki, ilgili gruba 1 (bir) puan olarak kayıt edilmiştir. Bu kısımdan bir grubun alabileceği puan en fazla 10 (on) puandır. (2) Eşleştirme: Kart-01 ve Kart-02'nin eşleştirilmiştir. Burada da her doğru eşleştirmeye 1 (bir) puan verilmiştir. Toplam 10 eşleştirme vardır. En fazla 10 (on) puan alabilir. Etkinlik süresince, her soru için tek cevap hakkı verilmiştir. Yanlış cevaplar puanlanmaya dâhil edilmemiștir, sıfır olarak gösterilmiştir. Cevap hakkı kullanılmayan 
durumlar "Cevap Yok" olarak gösterilmiştir. Bu iki puanlamanın (Bitki konumu bulma ve Eşleştirme) toplamından gruplara “Konum Bul” etkinlik puanı verilmiştir.

Yapılandırılmış (Görüşme A-bireysel, Görüşme B-grup) ve serbest (Görüşme C-grup) formlarıyla, derinlemesine bilgi edinmek ve çalışmanın geçerliliğini artırmak hedeflenmiştir (Tablo 1) [78]. Görüşme A ve B'de ki sorular yazılı cevaplandırılmıştır. Genel serbest görüşme (C) notları üç kişi tarafından tutulmuştur. Görüşmenin sonunda notlar karşılaştırılmış ve katılımcılarla paylaşılarak son şekli verilmiştir. Dersi hazırlayan öğretmen adaylarının saha notları haftalık görüşmelerde incelenmiş ve görüşmeleri desteklemek için kullanılmıştır. Portfolyo değerlendirmesinde, rubrik (Ek 1) her gruba basılı olarak verilmiştir. Sekiz grubun aritmetik ortalaması alınarak portfolyo puanı hesaplanmıştır.

Son olarak, katılımcılar, dersi veren sınıf arkadaşlarının performanslarını bireysel ve grup olmak üzere iki düzeyde 100 üzerinden puanlamışlardır. Her iki puanlamanın aritmetik ortalaması ayrı ayrı alınarak ders sonunda iki performans puanı verilmiştir. Dönüt amaçlı yapılan bu puanlama, sıralama ve notlama olarak kullanılmamıştır.

\subsection{Geçerlik, güvenirlik ve etik}

Veriler kodladıktan sonra, kodlar ve temalar iki akademisyen tarafindan birbirinden bağımsız olarak kontrol etmiştir. İçsel tutarlılık Miles ve Huberman (2015) formülüne göre $^{6} \%$ 86, 88 olarak bulunmuştur. İçsel tutarlılığ1 veren kodlama denetimine göre kodlayıcılar arası görüş birliğinin en az \% 80 olması beklenmektedir [79-81]. Yapılandırılmış ve serbest formda görüşmeler, portfolyo ve saha notları yoluyla bilgi toplanarak veri üçgenlendirilmesi yapılmıştır [82]. Çalışma ve süreçle ilgili detaylı tanımlamayla dış güvenirlilik sağlanmıştır [83].

\section{Bulgular}

$\mathrm{Bu}$ çalışmada (1) Sınıf dışında uygulamaya dayalı dersin öğretiminde ders araştırmalarının, fen öğretmeni adaylarının mesleki becerilerine ve biyoloji alan bilgilerine katkısı nedir? ve (2) Fen bilgisi öğretmen adayları ders araştırmalarının yararlılığını ve uygulanabilirliğini nasıl değerlendiriyor? araştırma sorulara cevap aranmıştır. İlk araştırma sorusu kapsamında, "Konum Bul" etkinliği çerçevesinde elde edilen bulgular aşağıda verilmiştir.

"Ön Bahçe" de yapılan etkinliğin, ilk kısmında , Bitki Konum Bul, gruplar 3 puan (bir grup) ve 8 puan (bir grup) arasında puan almıştır (Bkz. Hafta 8). Altı grubun puanı 4-6 aralığında değişirken, tam puan (10) alan grup olmamıştır. Dört gruptaki öğretmen adayları sürenin az olduğunu ve bahçenin orta kısmına odaklandıklarını söyleyerek, A Blokun yan kısımlarında olan Olea europaea (yıldız işaretiyle kodlanan) ve Larix kaempferi (okla işaretlenen) (Şekil-1) bitkilerin dikkatlerinden kaçtı̆̆ını belirtmişlerdir. Ancak, bahçenin orta kısmında olan renk olarak diğerlerinden farklı ve gövdesi de dikenli olduğu belirtilen (Kart-01'den bilgi), Juniperus sabina'nın da konumunu tespit edemeyen dört grup olmuştur. Türkiye ormanlarının asli ağaç türlerinden [84] Larix kaemferi ve Pinus sylvestris aynı zamanda yerleşkedeki en yaygın iki ağaç türü olmasına rağmen öğretmen adayları bu iki bitkiyi hem konum tespitinde hemde ikinci kısımda, Eşleştirme, karıştırmışlardır. Eugenia polyantha, Trachicarpus fortunei ve Olea europaea kart eşlemede, tüm gruplar tarafindan en çabuk belirlenen bitkiler olmuştur. "Konum Bul" toplam puanı, 7 (bir grup) ve 13 (iki grup) puan arasında değişmiştir. Tüm gruplar cevap 
hakkını kullanmıştır. Etkinliğinin sınıf seviyelerine uyarlanması konusunda, öğretmen adaylarının tamamı, "Konum Bul" aktivitesinin 3-8 sınıf seviyesinde beş bitkiyle yapılabilecek bir çalışma olduğuna hemfikir olmuşlardır. Ancak, 7. ve 8. sınıf seviyesindeki öğrencilerin sınav hazırlığına öncelik verdikleri için böyle bir etkinliğe ne kadar aktif katılacaklarını tahmin edemediklerini belirtmişlerdir. Kendi öğrenci grupları için bilgi kartlarında (Kart-01) beslenme ve tıbbı kullanım alanları içeren bilgilere öncelik verilmesi görüşünde oldukları görülmüştür. Örneğin;

Ö-5 “ Hepsi önemli ama hi...bence ögrencilerimin să̆llklı beslenme konusunda bilgi sahibi olmas1 daha önemli."

Öğretmen adayları dersin hem hazırlık hem de işlenmesinde bitkilerin bilimsel isminin kullanması ve bu isimlerin bulunmasında farkındalıklarının olduğunu ancak kendilerini yeterli hissetmediklerini belirtmişlerdir. Kurutulmuş yaprak örnekleri ve çizimleri (Kart02), öğretmen adayları tarafından öğrencileriyle rahat yapabilecekleri bir çalışma olarak görülmüştür. Örneğin;

Ö-16 " Ezberliyordum ama...., tam olarak hiç anlamadım. Bazllarının isimlerini tanıyabiliyorum, ....ehh şöyle böyle... ama gene de bence tam, doğru bir şey demem zor." Ö-28 “ Kuru yapraklar çok hoş gözüküyor, çizimleri yapabileceğimi sanmıyorum ama ögrencilerimle denemek isterim, onlar için keyifli olabilir."

Bu çalışmanın, etkinlikten önce yapılmasının öğrencilerin bitkileri tanıması ve çalışmaya hazırlıklı olmalarını sağlayacağı konusunda fikir birliği oluşmuştur. Örneğin,

$\ddot{O}$-10 "Kendi ögrencilerimle önce yaprak çizimleri yapmak isterim, bence bu şekilde daha keyifli olur.".

Ö-12 "SSimdide öğrendik ama . bence önce hepimiz yaprak toplayı, sonra hangi bitkilerle çalışılacak karar verseydik daha fazla sayıda bitki tanıyabilirdik... daha fazla bilgimiz olabilirdi."

İkinci araştırma sorusu kapsamında yapılan üç farklı görüşmeden (A, B, C) elde edilen sonuçlar özetle aşağıdaki verilmiştir. Dersi hazırlayan üç öğretmen adayıyla yapılan haftalık yapılandırılmış görüşme (A)'da, toplam 7 görüşme yapılmıştır. Bu görüşmeler, saha notlarıyla desteklenerek dersin hazırlık süreci takip edilmiştir (Tablo 1). Öğretmen adaylarının görüşmelerde kendilerine yöneltilen beş soruya cevapları aşağıda verilmiştir.

Görüşme A:

“Bu haftaki çalışma 100 üzerinden kaç puan verirsiniz?” (A-Soru-1).

Çalışma alanının belirlendiği 4. hafta, dersi hazırlayan üç öğretmen adayı kendilerini 90 , 93 ve 95 puanla olarak, diğer haftalarda ise 60-85 aralığında puanlamışlardır. Özellikle bitki türlerinin belirlenip ön hazırlıkların gözden geçirildiği 6 . ve 7. haftalarda öğretmen adayları kendilerine en alt seviyede puan vermişlerdir.

"Bu hafta ki çalışmanız ve geçen hafta ki çalışmanız arasında değerlendirme yaptığınızda sizce çalışmanız hangi kısımları ilerledi?" (A-Soru-2)

Dersi hazırlayan öğretmen adayları ilk üç haftada çalışmada ilerleme görmemişlerdir. Çalışma yapılacak konumun belirlenmesinden (Tablo 1, Hafta 04) sonra, görüşmelerde çalışmanın kendileri için daha netleştiğini ve ilerlediğini düşündüklerini belirtmişlerdir. Takip eden haftalarda Kart-01 ve Kart-02 hazırlığına yoğunlaşılmıştır. Dönütlere göre hazırlıklarını güncellemişlerdir. Çalışmanın ilerlediğini düşündükleri noktaları da bu dönütlere göre yaptıkları güncellemelerle ilişkilendirmişlerdir. Sonrasında, ders planı, 
istasyonların belirlenmesi ve özellikle bitki çeşitliliği konusunda çalışmanın ilerlediğini ve kendi kazanımlarının da arttığını belirtmişlerdir.

"Kendinizi bu aşamada, dersi sınıf dışında tek başınıza verecek yeterlilikte hissediyor musunuz? (A-Soru-3)

Bu soruyu öğretmen adayları ilk haftalarda "evet" veya "hayır" şeklinde cevaplamaktan ziyade şartların oluşması, sınıf seviyesi, konu hakkında kendilerini yeterli hissetmeleriyle ilişkilendirilerek cevaplandırmışlardır. $\mathrm{Bu}$ durum haftalara göre dalgalanmalar göstermekle birlikte temkinli cevaplarına devam etmişlerdir. Öğretmen adaylarının ders vermede istekli oldukları görülmüştür.

\section{"Dersi bu aşamada tek veya şu anki grup arkadaşlarınızla mı vermek istersiniz?"} (A-Soru-4)

Ders planları şekillendikçe kendi hazırlıklarına güvenleri artmıştır. Üç öğretmen adayı 7. hafta da, son provadan sonra, dersi tek başına verebilme yeterliliği hissettiklerini belirmişlerdir. Ancak çalışmanın hazırlığının tek kişi için çok yoğun olduğunu ve grup çalışması olmasından memnuniyetlerini dile getirmişlerdir. $\mathrm{Bu}$ nedenle dersi grup arkadaşlarıyla vermek istediklerini, uyumlu çalıştıklarını ve iş bölümü yapabildikleri için zaman açısından rahat ettiklerini söylemişlerdir.

\section{"Ekip çalışmasında sizce önemli olan nedir?” (A-Soru-5)}

4. haftaya kadar grubu oluşturmada etkili olan arkadaşlıkları, birbirlerine yardım edebildikleri ve destek oldukları için birlikte çalışmak istediklerini belirtmişlerdir. İlerleyen haftalarda çalışma sorumluluğu, karşılıklı anlayış, hoşgörü, ölçülü ve seviyeli davranmanın önemine dikkat çekmişlerdir. Özellikle kartların hazırlanmasında ekip çalışmasında sorumluluğun ve iş hassasiyetinin öneminden bahsedip, grupta kimsenin işten kaçmadığı için çalışmada sıkıntı çekmediklerini belirtmişlerdir.

Görüşme B:

Ders sonunda sekiz grupla (toplam 38 katılımcı öğretmen adayıyla) yapılan görüşme (B)'de alınan cevaplar özetle aşağıdaki şekildedir.

“Bu çalışmada öğrenme açısından verimli bulduğunuz üç şey nedir?” (B-Soru-1)

Dersin planlı ve rahat takip ediliyor olması (altı grup), kaynakçanın paylaşılması (dört grup), bahçenin genel turunun yapılması (sekiz grup) verimli bulmuştur. Tüm gruplar dersin, ders içeriği yanı sıra hareketli olarak planlanmış olmasından dolayı sürenin hem çabuk hem de kazanımla geçtiğini belirtmişlerdir.

"Bu çalışmada öğrenme açısından geliştirilmesi gerektiğini düşündüğünüz üç şey nedir?" (B-Soru-2)

Sürenin uzatılması veya bitki türü sayısının azaltılması (beş grup), kendilerine "Ön Bahçe" krokisiyle birlikte ders planının da verilmesi (dört grup), sesin her zaman rahat duyulmadığını ve takip edemedikleri (altı grup) belirtmişlerdir.

Görüşme C:

Ders sonunda serbest formatta zaman sınırlaması olmadan yapılan görüşme $(\mathrm{C})$, toplam 30 dakika sürmüştür. Bu görüşme sonuçları üç başlıkta toplanmıştır. 
(a) Bitki çeşitliliği:

Öğretmen adayları, yerleşkede gözden kaçırdıkları ve fark etmedikleri çok bitki olduğu konusunda hemfikir olmuşlardır. Bazı bitkilerin hiç tanımadıkları ve bilgileri olmadığına şaşırdıklarını belirtmişlerdir. Özellikle Pinus sylvestris ve Larix kaemferi karıştırmaları ve yerleşkede Trachicarpus fortunei bu çalışmaya kadar fark etmemeleri ön plana çıkmıştır.

\section{(b) Ders Planı ve Ön Hazırlı}

Öğretmen adayları sınıf dışında ders planının etkin kullanımı, istasyonlarda bilgilendirme, dersin hareketli olmasının kendileri için yeni olduğunu belirtmişlerdir. Böyle bir çalışma için hazırlıklı olmalarının önemli olduğunu, ders için belirlenen konumum kendilerine en az bir hafta önceden bildirilmesinin, bitki çeşitliliğini tanımalarında ve derse katılımlarında faydalı olacağını söylemişlerdir. Katılımcıların diğer önerisi kendilerinin de 10 bitki seçerek derse hazırlıklı gelmeleri şeklinde olmuştur.

Örnek öğretmen adayı cevabı aşağıda sunulmuştur.

$\ddot{O}-22 \ldots .$. Eğer çalışmanın burada yapılacağını bilseydim, bende bitkilere bakardım. Her gün bahçenin önünden geçiyoruz ama hep telaş içindeyiz. Hiç aklıma gelmedi bakmak şu ana kadar..."

\section{(c)Teknoloji Kullanımı}

Ders süresince taksonomi bilgisayar uygulamaları, cep telefon fonksiyonlarını kullanmaları (örn. kameranın büyütme seçeneği, yön tayin etme), ders materyaline ${ }^{5}$ ulaşabilmeleri ve internet erişimlerinin açık olmasının kendilerinin var olan imkânlarını ne kadar az kullandıklarının fark etmelerini sağladığını belirtmişlerdir. Dersin tekrarı veya yeniden düzenlenmesi durumunda, çalışma alanı belirlendikten sonra kendileriyle paylaşılması önerisini yenilemişlerdir.

Son olarak, katılımcılar üç öğretmen adayı tarafından ders hazırlığı sırasında düzenlenen portfolyoyu verilen rubrike göre (Ek 1) değerlendirmişlerdir. Bu puanlamanın 95-100 arasında değiştiği görülmüştür. Saha notlarını incelenmiştir. Katılımcılar, kendi bireysel performanslarını, dersi rahat takip ettiklerini belirterek 90 ve üstünde puanlamışlardır. Sekiz grubun kendilerini değerlendirdiklerinde, grup puanlarının 83-97 puan aralığında olduğu görülmüştür. Uygulama dersini veren üç öğretmen adayının grup ve bireysel performansı katılımcılar tarafından tam puan (100) olarak puanlanmıştır.

\section{Sonuç, tartışma ve öneriler}

Bu çalışmada fen bilgisi öğretmen adaylarınca ders araştırması modeline göre hazırlanan dersin, mobile teknolojiyle zenginleştirilmiş sınıf dışı karma öğrenme ortamında (yerleşke bahçesi) sınıf arkadaşlarına aktarmaları paylaşılmıştır.

İlk araştırma sorusu kapsamında, yapılan incelemede; öğretmen adayları, dersin hem hazırlık hem de işlenmesinde bitkilerin bilimsel isminin kullanması ve bu isimlerin bulunmasında farkındalıklarının olduğunu ancak kendilerini yeterli hissetmediklerini belirtmişlerdir. Bu sonuç alan yazıdaki diğer çalışmalarda [85-87] elde edilen bulgularla benzerlik göstermekte, alan eğitiminde taksonomi konusundaki sıkıntılara tekrar dikkat çekmektedir. 
Çalışmada, klasik taksonomi yöntemleri yanı sıra, dijital kaynaklar ve bilgisayar uygulamaları eş zamanlı kullanılmıştır. Üniversite öğrencilerinin akıllı telefon kullanım süreleri günlük ortalama 4 saat ve üzerinde olduğu belirtilmiştir [88]. Öğretmenlerin teknolojiyi kendi eğitim ve öğrenim süreçlerinde kullanabilmeleri, değişen öğrenme ortamlarına ve şartlarına kendi eğitim süreçlerinden başlayarak etkin ve aktif uyumları gerekmektedir. $\mathrm{Bu}$ aynı zamanda mobil teknolojinin öğretmenlik mesleği sürecinde kullanma olasılıklarını beraberinde getirmektedir [89-91].

Çalışma süresince, etkinliğinin sınıf seviyelerine uyarlanması konusunda, öğretmen adayları görüşlerini belirtmekle zorlandıkları görülmüştür. Öğretmen adaylarının henüz gerçek sınıf ortamlarında deneyimleri olmamasının çalışmanın sınırlıkları arasında bulunduğu belirtilerek, ders materyalini farklı sınıf seviyelerine uyarlamada alan bilgisi ve pedagojik donanımın etkili olduğu görülmektedir. Uygulama dersi alan öğretmen adayları veya hizmet içi programlarda yapılacak çalışmaların bu konuda alan yazına katkı sağlayacağı düşünülmektedir.

Günümüz şartlarında, özellikle Covid-19 pandemi sürecinin eğitimdeki en görünür etkisi yaşamın içindeki teknolojinin eğitim hedeflerine yöneltilmesinin ivedi gerekliliğini beraberinde getirmiştir [92,93]. Biyoloji eğitiminde mobile teknolojiyle desteklenen karma öğrenme ortamlarıyla öğretmen yetiştirme programlarının güçlendirilmesi ve bunun uygulamayla desteklenmesinin öğretmen adaylarının alan yeterliliklerinin güçlendireceği düşünülmektedir.

İkinci araştırma sorusu kapsamında Görüşme (A) ve (B) sonuçları incelendiğinde, ders araştırmaları modeline göre takip edilen programın ögretmen adaylarının özgüven ve bilgilerini desteklenmesi ve mesleki gelişimlerine katkısının alan yazınla uyumlu olduğu görülmüştür $[94,95]$. Çalışmada yapılan bireysel ve grup değerlendirmelerini de, alan yazıyla benzer şekilde öğretmen adayları tarafından mesleki gelişimleri için faydalı bulmuştur [96, 69, 97].

Çalışmalar, okulun sadece öğrenci için değil öğretmenler içinde bir öğrenme ortamı olduğunu ve bu ortamda öğretmenlerin işbirlikçi meslek kültürünü kazanmaları ve profesyonel gelişimi destekleyici davranışlarının önemli olduğunu göstermiştir. Ancak, öğretmenlerimizin işbirliğiyle öğrenmedikleri, meslektaşlarının derslerini gözlemlemedikleri ve birbirlerine dönüt vermedikleri görülmüştür [98]. Bunda öğretmenlerin sınıflarının özel bir alan olduğu algısından kaynaklanabileceği düşünülmektedir [99]. Buna karşın PISA ve TIMMS sonuçlarının yüksek olduğu ülkelerden örneğin Japonya'da, öğretmenlerin derslerinin kalitesini artırmak için işbirlikçi çalıştıkları, derslerini gözledikleri, etkili öğretme yöntemlerini paylaştıklarını ve kurumsallaştırdıkları aynı zamanda da mesleki gelişimlerine katkı gösterdikleri paylaşılmıştır [100-102]. Alan yazıdaki bu sonuçlara bakarak, öğretmen eğitiminden başlayarak, öğretmenlere işbirlikçi öğrenme ve birbirlerinin profesyonel gelişimini destekleyici dönütler vererek, birbirlerinin alan ve mesleği yeterliliklerine destek olmalarının geliştirilmesi gerektiği ön görülebilir.

$\mathrm{Bu}$ çalışmada, dersi veren grubun değerlendirmeye katılması, puanlamanın yüksek olmasında etkili olabilir ancak öğretmen adaylarının birbirilerinin dönütleri alabilme ve fikirleri paylaşma ve kendilerini açıklamaları gereken noktalar olabileceği düşünülerek çalışma düzeninde bu şekilde kalması planlanmıştır. Yukarıda verilen alan yazı kapsamında, tartışma kültürünün ve görüş alışverişi ortamının güçlendirilmesi amacıyla, 
çalışma süresince bireysel ve grup bazında öz değerlendirmelerle, öğretmen adaylarının değerlendirme sürecinde aktif olmaları sağlanmıştır. $\mathrm{Bu}$ kapsamda, araştırma sonuçlarının ve ders araştırmaları çalışmalarının, öğretmenlik mesleğini, eğitim sürecinden başlayarak destekleyeceği düşünülmektedir.

Öğretmen adayları, ders hazırlığının zaman aldığını söyleyerek süreci uzun bulmuşlardır. $\mathrm{Bu}$ sonuç, Bayram ve Canaran'in [61] deneyimli öğretmenlerle yaptığı çalışmayla benzerlik göstermiştir. Alan yazıda da belirtildiği şekilde yapılacak olan çalışmalarda modelin çalışma gruplarına göre uyarlanması gerekebilir [55, 92, 54].

Sonuç olarak, "Ders Araştırma" modelinin, öğretmen adaylarının işbirlikçi yaklaşım, profesyonel iletişim, birlikte öğrenme ve bireysel-grup olarak öz değerlendirebilme becerilerine destekleyerek, mesleki ve alan yeterliliklerine katkı sağlayacağı bu çalışmada da görülmüştür. Araştırma sonuçlarının, fen bilgisi öğretmenlerinin eğitim sürecinden başlayarak sınıf dışı öğretim etkinliklerinde farkındalıklarının kazandırılmasına ve okul bahçelerinin, sınıf dışındaki öğrenme ortamları olarak, sınıf kapısından başlayarak alan eğitiminde işlevsel olmasına katkı sağlayacağı beklenmektedir.

\section{Notlar}

1. Modelin uygulama süresi farklılıklar göstermektedir. Japonya'da uygulandığı şekliyle ders çalışma döngüsünün tüm bileşenlerinin tamamlanması için 5 hafta yeterli görülmektedir [5]. Bu çalışmaya katılan grubun Okul Deneyimi ve Öğretmenlik Uygulama derslerini henüz almadıkları göz önünde bulundurularak süre 8 haftaya olarak belirlendi ve bazı haftalarda tekrarlarla ilerlendi.

2. Çanakkale Onsekiz Mart Üniversitesi Eğitim Fakültesi Kampüsü 2019 y1lından yenilenmiştir. Çalışmanın yapıldığı yerleşkenin 6dk., 12sn. lik sanal turu görsellerde kullanıldı [75] Eğitim Fakültesi, Yenilenen Yerleşkesinde Eğitim Öğretime Başladı (2020) https://www.comu.edu.tr/haber-18607.html (Erişim Tarihi:17/12/2021)

Fakültemiz Hakkında (2020).http://egitim.comu.edu.tr/fakultemiz/fakultemiz-hakkindar2.html (Erişim Tarihi:17/12/2021)

3. Sayfalara 17.12.2021 tarihinde erişildi.

○ T. C. Tarım ve Orman Bakanlığı Orman Genel Müdürlüğü

https://www.ogm.gov.tr/

○ T.C. Tarım ve Orman Bakanlığı Türkiye Milli Botanik Bahçesi Müdürlüğü

https://arastirma.tarimorman.gov.tr/millibotanik

○ GARDENIA Creating Gardens https://www.gardenia.net/plant/olea-europaea

○ Online Bitki Veritaban1 https://www.bitkivt.itu.edu.tr/

○ Nezahat Gökyiğit Botanik Bahçesi http://ngbb.org.tr/

○ İstanbul Üniversitesi Müze ve Kültür Miraslarının Yönetimi Uygulama ve

Araştırma Merkezi

https://muzeyum.istanbul.edu.tr/tr/content/koleksiyon/koleksiyonlar

○ iPlanzen https://apps.apple.com/us/app/ipflanzen/id416983587

○ Die Waldfibel 4+ Bundesministerium für Ernährung und Landwirtschaft

https://apps.apple.com/gb/app/die-waldfibel/id453746100

○ Pl@ntNet https://identify.plantnet.org/

○ Türkiye Florası

https://www.turkiyeflorasi.org.tr/ 
4. Uma, M. M., ve Düzenli, A. (2010). Bitki toplama, teşhis ve herbaryum teknikleri (Doctoral dissertation, Yüksek Lisans Tezi, Çukurova Üniversitesi Fen Bilimleri Enstitüsü, Adana). http://libratez.cu.edu.tr/tezler/8225.pdf

○ Herbaryum yapma Teknikleri ve Yabancı Ot Teşhis Yöntemleri (1998)

https://www.researchgate.net/profile/Huseyin_Onen/publication/287759991_Herbary um_Yapma_Teknikleri_ve_Yabanci_Ot_Teshis_Yontemleri_Herbarium_Techniques _and_Identification_of_Weed_Species/links/574c533b08ae78f2d2017fc7/Herbaryu m-Yapma-Teknikleri-ve-Yabanci-Ot-Teshis-Yoentemleri-Herbarium-Techniquesand-Identification-of-Weed-Species.pdf

○ Herbaryum Teknikleri https://www.ktu.edu.tr/ormanbotanigi-herbaryumteknikleri

○ Biyolojide Çizim Tekniği

http://uguner.trakya.edu.tr/GenelBiyo/Destek-3.html

- A LEVEL BIOLOGY DRAWING SKILLS Biological Drawing

https://drive.google.com/u/0/uc?id=0B7EoydxcWA7paDRvekk0cmpzbW8\&export= download

5. Bu çalışmanın yapıldığı, FEN136 Genel Biyoloji II dersi öğrencilerin tüm ders materyaline http://moodle.comu.edu.tr/_üzerinden erişiminin sağlamıştır ve mobile teknolojinin (akıllı telefon, tablet vb.) kullanıldığ 1 karma (hibrit) ders ortamı olarak tasarlanmıştır. Öğretmen adaylarına mobile teknolojinin ve internetin ders amaçlarına uygun kullanımıyla ilgili bilgilendirme, ders izlencesiyle birlikte verilmiştir.

6. İçsel tutarlılık Miles ve Huberman (2015) formülü

$[\Delta=\mathrm{C} \div(\mathrm{C}+\partial) \times 100]$

$\Delta:$ Güvenirlik katsayısını

C Üzerinde görüş birliği sağlanan konu/terim sayısını

$\partial$ : Üzerinde görüş birliği bulunmayan konu/terim sayısı

\section{Teşekkür}

Yazar çalışmaya gönüllü katılan Fen Bilgisi Eğitimi öğrencilerine teşekkür etmektedir.

\section{Kaynaklar}

[1] den Brok, P. J., Wubbels, T., ve van Tartwijk, J. W. F. Exploring beginning teachers' attrition in the Netherlands. Teachers and Teaching, 23, 881-895. (2017)

[2] Harmsen, R., Helms-Lorenz, M., Maulana, R., ve van Veen, K.. The relationship between beginning teachers' stress causes, stress responses, teaching behaviour and attrition. Teachers and Teaching, 24(6), 626-643. (2018)

[3] Kim, H., ve Cho, Y. Preservice teachers' motivation, teacher efficacy, and expectation of reality shock. Asia-pacific Journal of Teacher Education, 42(1), 67-81. (2014).

[4] Räsänen, K., Pietarinen, J., Pyhältö, K., Soini, T., ve Väisänen, P. Why leave the teaching profession? A longitudinal approach to the prevalence and persistence of teacher turnover intentions. 23, 837-859,Social Psychology of Education. (2020).

[5] Varah, L. J., Theune, W. S., ve Parker, L. Beginning teachers: Sink or swim?.Journal of teacher education, 37(1), 30-34. (1986). 
[6] Bulunuz, N., ve Bulunuz, M. Öğretmen adaylarının mesleki gelişimi için iyi öğretmenlik uygulamaları: Klinik danışmanlık modeli. Uludă Ŭniversitesi Ĕ̆itim Fakültesi Dergisi, 29(2), 401-429. (2016)

[7] Gürsoy, E., Bulunuz, N., Göktalay, S. B., Bulunuz, M., Kesner, J., ve Salihoğlu, U. Clinical supervision model to improve supervisory skills of cooperating teachers and university supervisors during teaching practice. Hacettepe Üniversity Journal of Education, Özel say1, 1, 191-203. (2013)

[8] Mansfield, C., ve Beltman, S. Promoting resilience for teachers: pre-service and in-service professional learning. The Australian Educational Researcher 46, 583-588 (2019).

[9] Mansfield, C., ve Gu, Q. "I'm finally getting that help that I needed": Early career teacher induction and professional learning. The Australian Educational Researcher, 46(4), 639-659. (2019).

[10] Ballantyne, J., Flynn, L., ve Olm-Madden, T. Problem-seeking in teacher education: Empowering students to grapple with the complexities of the profession. Australian Journal of Teacher Education, 45(5),38-61. (2020)

[11] Akben, N.. Uygulamaya dayalı fen öğretimine ilişkin sınıf öğretmeni adaylarının görüşleri. Ankara Üniversitesi Eğitim Bilimleri Fakültesi Dergisi, 51(3) 145167, (2018)

[12] Akin, S. ve Sözen-Özdogan, S. Öğretmen Eğitiminde Yapıtaşı: Türkiye, Singapur ve Hong Kong'da Öğretmenlik Mesleği Genel Yeterlikleri. Ankara Üniversitesi Eğitim Bilimleri Fakültesi Dergisi, 54(1),269-311. (2021)

[13] Dunst, C. J., Hamby, D. W., Howse, R. B., Wilkie, H., ve Annas, K. Research Synthesis of Meta-Analyses of Preservice Teacher Preparation Practices in Higher Education. Higher Education Studies, 10(1), 29-47. (2020)

[14] Heikonen, L., Pietarinen, J., Pyhältö, K., Toom, A., ve Soini, T. Early career teachers' sense of professional agency in the classroom: associations with turnover intentions and perceived inadequacy in teacher-student interaction, Asia-Pacific Journal of Teacher Education, 45 (3), 250-266. (2017)

[15] Fraser, B. J., ve Walberg, H. J. Educational environments: Evaluation, antecedents and consequences. Oxford: Pergamon Press. (1991)

[16] Haertel, G. D., Walberg, H. J., ve Haertel, E. H. Socio-psycological environments and learning: A quantitative synthesis. British Educational Research Journal, 7(1), 27-36. (1981)

[17] Mercin, L. Müze Eğitimi, Bilgilendirme ve Tanitim Açisindan Görsel İletişim Tasarimi Ürünlerinin Önemi. Milli Eğitim Dergisi, 46 (214), 209-237. (2017).

[18] Şimsek, G., Acar, E., Atalan-Çayirezmez, N., ve Elitok-Kesici, A. Exploring the role of the city as a learning environment for heritage education. METU Journal of the Faculty of Architecture, 30(2),105-135. (2013).

[19] DeWitt, J., ve Osborne, J. Supporting teachers on science-focused school trips: Towards an integrated framework of theory and practice. International journal of science education, 29(6), 685-710. (2007)

[20] Lane, J. F.; Ateşkan, A. ve Dulun, Ö. Turkish teachers' use of the outdoors as a teaching resource: Perceived facilitators and obstacles, Applied Environmental Education \& Communication, 17(1), 14-28, (2018)

[21] Köseoğlu, F., Tahancalı, S., Kanlı, U., ve Y1lmaz, Y. Ö. Öğretmenlerin Bilim Merkezlerinde Öğrenmeye Yönelik Mesleki Gelişim İhtiyaçlarının Araştırılması. Eğitim ve Bilim, 45 (203), 191-213. (2020). 
[22] Ateşkan, A. ve Lane, J. F. Promoting field trip confidence: teachers providing insights for pre-service education, European Journal of Teacher Education, 39(2), 190-201. (2016)

[23] Cox-Petersen, A. M., ve Pfaffinger, J. A. Teacher preparation and teacher-student interactions at a discovery center of natural history. Journal of Elementary Science Education, 10(2), 20-35. (1998)

[24] Eshach, H. Bridging in-school and out-of-school learning: Formal, non-formal, and informal education. Journal of science education and technology, 16(2), 171-190. (2007)

[25] Olson, J. K., Cox-Petersen, A. M., ve McComas, W. F.. The inclusion of informal environments in scienceteacher preparation. Journal of Science Teacher Education, 12, 155-173. (2001)

[26] Çıldır, Z., ve Karadeniz, C. Okul Öncesi Öğretmen Adaylarının Görüşleri Bağlamında Müze ve Müzede Eğitim. Milli Eğitim Dergisi, 46(214), 359-383. (2014)

[27] Taşdemir, A., Kartal, T., \& Özdemir, M. A. Using science centers and museums in teacher training. The Asia Pacific Education Researcher, 127, 298-308. (2013).

[28] School Gardens Nature 61, 455-456. (1900).

[29] The Educational Value of the School Garden Nature 84, 220. (1910).

[30] Akdoğan, G. Beş Büyük Şehirde Çocuk Oyun Alanları, Okul Bahçeleri ve Spor Alanlarının Yeterlilikleri ve Planlama Prensipleri Üzerine Bir Araştırma. Ankara Üniversitesi Ziraat Fakültesi Yayınları, 522. (1972)

[31] Karakaya, B., ve Kiper, T. Edirne kent merkezindeki bazı ilköğretim okul bahçelerinin peyzaj tasarım ilkeleri açısından mevcut durumunun belirlenmesi. Tekirdağ Ziraat Fakültesi Dergisi, (10)1,59-71. (2013)

[32] Şişman, E. E., ve Gültürk, P. İlköğretim okul bahçelerinin peyzaj planlama ve tasarım ilkeleri açısından incelenmesi: Tekirdağ örneği. Tekirdă Ziraat Fakültesi Dergisi, 8(3), 53-60. (2011).

[33] Akpinar, A. How is high school greenness related to students' restoration and health?. Urban forestry \& urban greening, 16, 1-8. (2016)

[34] Özer, E. J. (2007). The effects of school gardens on students and schools: Conceptualization and considerations for maximizing healthy development. Health Education \& Behavior, 34(6), 846-863.

[35] Suri, S. Nutrition Gardens: A Sustainable Model for Food Security and Diversity. ORF issue brief, (369). (2020).

[36] Kim, S. O., ve Park, S. Garden-Based Integrated Intervention for Improving Children's Eating Behavior for Vegetables. International Journal of Environmental Research and Public Health, 17(4), 1257. (2020).

[37] Karatekin, K., ve Çetinkaya, G. Okul Bahçelerinin Çevre Eğitimi Açısından Değerlendirilmesi (Manisa İli Örneği). Journal of International Social Research, 6 (27). (2013)

[38] Carrion, C. A. "Do students gain scientific inquiry knowledge and practices by participating in a school garden inquiry unit?." Dissertation, Georgia State University, https://scholarworks.gsu.edu/mse_diss/101 (2020)

[39] Ürey, M. ve Çepni, S. Serbest Etkinlik Çalışmaları Dersine Yönelik Bir Program Önerisi: Okul Bahçesi Programı. Milli Eğitim Dergisi, 44(202), 37-58. (2014).

[40] Passy, R. School gardens: teaching and learning outside the front door, Education 3-13, 42(1), 23-38. (2014). 
[41] Ürey, M. Bahçe temelli öğrenme yaklaşımına yönelik eğilimler: Okul bahçesi uygulamaları örneği (2000-2015). Yüzüncü Yıl Üniversitesi Eğitim Fakültesi Dergisi, 15 (1), 1054-1080. (2018)

[42] Yıldırım, A. Teacher education research in Turkey: Trends, issues and priority areas. Egitim ve Bilim, 38(169). (2013)

[43] Graham, H., Beall, D. L., Lussier, M., McLaughlin, P., ve Zidenberg-Cherr, S. Use of school gardens in academic instruction. Journal of Nutrition Education and behavior, 37 (3), 147-151. (2005)

[44] van Dijk-Wesselius, J. E., van den Berg, A. E., Maas, J., ve Hovinga, D. Green Schoolyards as Outdoor Learning Environments: Barriers and Solutions as Experienced by Primary School Teachers. Frontiers in Psychology, 10, 2919. (2020).

[45] Elliott, J. What is lesson study? European Journal of Education, 54(2), 175188. (2019)

[46] Takahashi, A., ve Yoshida, M. Lesson-study communities. Teaching children mathematics, 10 (9), 436-437. (2004).

[47] Watanabe, T. Japanese lesson study in the United States. Educational Designer, 3(11), 1-13. (2018).

[48] Takahashi, A. The Role of the Knowledgeable Other in Lesson Study: Examining the Final Comments of Experienced Lesson Study Practitioners. Mathematics Teacher Education and Development, 16(1), n1. (2014).

[49] Borasi, R., ve Fonzi, J. Professional development that supports school mathematics reform. Washington, D.C.: National Science Foundation, Foundation Series. (2002)

[50] Cerbin, W., ve Kopp, B. Lesson study as a model for building pedagogical knowledge and improving teaching. International journal of teaching and learning in higher education, 18 (3), 250-257. (2006)

[51] Fernandez, C., ve Yoshida, M. Lesson Study: A case of a Japanese approach to improving instruction through school-based teacher development. Mahwah, NJ: Lawrence Erlbaum. (2004)

[52] Stigler, J., ve Hiebert, J. Closing the teaching gap. Phi Delta Kappan, 91, 32-37. (2009).

[53] Özdemir, S. M. Implementation of the Lesson Study as a Tool to Improve Students' Learning and Professional Development of Teachers. Participatory Educational Research, 6(1), 36-53. (2019).

[54] Wolthuis, F., van Veen, K., de Vries, S., ve Hubers, M. D. Between lethal and local adaptation: Lesson study as an organizational routine. International journal of educational research, 100, 101534. (2020).

[55] Takahashi, A., ve McDougal, T. Collaborative lesson research: Maximizing the impact of lesson study. ZDM: Mathematics Education, 48(4), 513-526. (2016).

[56] Çetin, G. Field trip to Kazdagi National Park: Views of prospective Biology teachers. Educational Research and Reviews, 9(19), 823. (2014)

[57] Çetin, G. Prospective Biology Teachers' Views about Field Trip to National Park. International Online Journal of Educational Sciences, 12(4).192-208 (2020)

[58] Butler, D. L., ve Winne, P. H. Feedback and self-regulated learning: A theoretical synthesis. Review of educational research, 65(3), 245-281. (1995)

[59] MEB (Millî Eğitim Bakanlığı). Öğretmenlik Mesleği Genel Yeterlilikleri Erişim 17.12.2021http://oygm.meb.gov.tr/meb_iys_dosyalar/2017_12/11115355_YYR ETMENLYK_MESLEYY_GENEL_YETERLYKLERY.pdf (2017a) 
[60] MEB (Ministry of National Education). Teaching strategy paper. Erisim 17.12.2021https://oygm.meb.gov.tr/meb_iys_dosyalar/2018_05/25170118_Teac her_Strategy_Paper_2017-2023.pdf (2017b).

[61] Bayram, I., ve Canaran, O. An Investigation of Turkish Novice EFL Teachers' Perceptions of Lesson Study. International Journal of Curriculum and Instruction, 11(1), 172-189. (2019)

[62] Coenders, F., ve Verhoef, N. Lesson study: professional development (PD) for beginning and experienced teachers. Professional development in education, 45(2), 217-230. (2019)

[63] de Vries, S., Roorda, G., ve van Veen, K. Lesson Study: Effectief en bruikbaar in het Nederlandse onderwijs? (pp. 405-17). Nationaal Regieorgaan Onderwijsonderzoek. (2017)

[64] Dudley, P. How Lesson Study works and why it creates excellent learning and teaching. Lesson study, 1-28. (2015)

[65] Lewis, C., Perry, R., Foster, D., Hurd, J., ve Fisher, L. Lesson study: Beyond coaching. Educational Leadership, 69 (2), 64-68. (2011).

[66] Godfrey, D., Seleznyov, S., Anders, J., Wollaston, N., ve Barrera-Pedemonte, F.. A developmental evaluation approach to lesson study: exploring the impact of lesson study in London schools. Professional Development in Education, 45(2), 325-340. (2019)

[67] Bayram-Jacobs, D. Professional development of Japanese science and physics teachers and Japanese approach in professional development:" lesson study". Ankara University, Journal of Faculty of Educational Sciences, 45 (2), 33. (2012)

[68] Günay, R., Yücel-Toy, B., ve Bahadir, E. Öğretmen Eğitiminde Ders Araştırması Modeli ve Türkiye'de Hizmet Öncesi Öğretmenlik Uygulamalarına Yönelik Bir Model Önerisi. Journal of International Social Research, 9 (42). (2016)

[69] Pektas, M. Effects of lesson study on science teacher candidates teaching efficacies. Educational Research and Reviews, 9(6), 164-172. (2014).

[70] Yalcin-Arslan, F.. The role of lesson study in teacher learning and professional development of EFL teachers in Turkey: A case study. TESOL Journal. (2019)

[71] Yılmaz, N. Öğretmen Adaylarının İstatistiği Öğretme Bilgilerinin Öğretmenlik Uygulaması Temelli Ders Araştırmaları Bağlamında İncelenmesi. Doktora tezi, Hacettepe Üniversitesi, Ankara. (2019)

[72] Mills, A. J., Durepos, G., ve Wiebe, E. Encyclopedia of case study research. London, England: Sage. (2010).

[73] Yin, R. K. Case study research: Design and methods. Los Angeles: Sage (2014).

[74] Acar, E.. Proje ve Portfolyo Değerlendirme S. Baştürk (Ed.), Eğitimde Ölçme ve Değerlendirme (sf. 229-251). Ankara: Nobel Yayıncılık. (2014)

[75] Y1ldiz, M. A. COMU 3D . https://www.youtube.com/watch?v=rhICyT6rxuA (Erişim Tarihi:17/12/2021) (2012)

[76] ÇOMÜ Tanıtım Filmi (Kısa) (2015) https://www.youtube.com/watch?v=tVPo3mGm9UM (Erişim Tarihi: $17 / 12 / 2021)$

[77] Kirazlı'dan Anafartalar'a Öğretmen Okulları(24 Kasım 2017) https://www.youtube.com/watch?v=UWVnLDpEyFA(Erişim Tarihi: 17/12/2021)

[78] Patton, M. Q. Qualitative research \& evaluation methods: Integrating theory and practice (4th ed.). Thousand Oaks, CA: Sage. (2015). 
[79] Miles, M. B., ve Huberman, A. M. Qualitative data analysis: An expanded sourcebook. Sage. (1994).

[80] Miles, M. B. ve Huberman, A. M. Nitel veri analizi (Trans. Ed. S. Akbaba ve AA. Ersoy). Ankara: Pegem Akademi. (2015).

[81] Patton, M. Q. Two decades of developments in qualitative inquiry: A personal, experiential perspective. Qualitative social work, 1(3), 261-283. (2002).

[82] Cohen, L., Mansion, L. ve Morrison, K. Research Methods in Education.6th ed. London: Routledge. p.25 (2007)

[83] O'Connor, C., ve Joffe, H.. Intercoder reliability in qualitative research: debates and practical guidelines. International Journal of Qualitative Methods, 19, 113, (2020)

[84] Orman Atlası T.C. Orman ve Su İşleri Bakanlığı Orman Genel Müdürlüğü (2020) http://www.turcev.org.tr/turcevCMS_V2/files/files/ORMAN\%20GENEL\%20M $\%$ C3\%9CD\%C3\%9CRL\%C3\%9C\%C4\%9E\%C3\%9C\%20ORMAN\%20ATLA SI.pdf (Erişim Tarihi:17/12/2021)

[85] Akar-Öztürk, E. Pre-Service Science Teachers' conceptions of systematics and taxonomy. Journal of Turkish Science Education, 13 (2), 37-48. (2016)

[86] Amprazis, A., ve Papadopoulou, P. Plant blindness: a faddish research interest or a substantive impediment to achieve sustainable development goals?. Environmental Education Research, 1-23. (2020)

[87] Bebbington, A. The ability of A-level students to name plants. Journal of Biological Education, 39(2), 63-67. (2005)

[88] Minaz, A., ve Bozkurt, Ö. Ç. Üniversite Öğrencilerinin Akıllı Telefon Bağımlılık Düzeylerinin ve Kullanım Amaçlarının Farklı Değişkenler Açısından İncelenmesi, Mehmet Akif Ersoy Üniversitesi Sosyal Bilimler Enstitüsü Dergisi, 9(21), 268-286. (2017).

[89] Ballantyne, J. Using Mobile Technologies and Problem-Seeking Pedagogies to Bridge Universities and Workplaces. In The Oxford Handbook of Technology and Music Education. (2017)

[90] Vavoula, G., Sharples, M., Rudman, P., Meek, J., ve Lonsdale, P. Myartspace: Design and evaluation of support for learning with multimedia phones between classrooms and museums. Computers \& Education, 53(2), 286-299. (2009).

[91] Zhang, B., Looi, C. K., Seow, P., Chia, G., Wong, L. H., Chen, W., ... ve Norris, C. Deconstructing and reconstructing: Transforming primary science learning via a mobilized curriculum. Computers \& Education, 55 (4), 1504-1523. (2010).

[92] Schleicher, A. The Impact of Covid-19 on education insights From Education At a Glance 2020. (2020).

[93] TEDMEM COVID-19 Sürecinde Eğitim Analiz A7 Uzaktan Öğrenme, Sorunlar ve Çözüm Önerileri (2020)

https://tedmem.org/yayin/covid-19-surecinde-egitim-uzaktan-ogrenme-sorunlarcozum-onerileri (Erişim 17/12/.2021)

[94] Bayram, İ., ve B1kmaz, F. Ders imecesi modeli ve modelin öğretmen mesleki gelişimine katkısı üzerine bir inceleme. Ankara Üniversitesi Eğitim Bilimleri Fakültesi Dergisi, 52 (2), 577-610. (2019)

[95] Handayani, R. A. D., Wilujeng, I., Prasetyo, Z. K., ve Triyanto. Building an indigenous learning community through lesson study: challenges of secondary school science teachers. International Journal of Science Education, 41(3), 281-296. (2019)

[96] Fernandez, M. L., ve Robinson, M. Prospective Teachers's perspective on Microteaching Lesson Study. Education, 127(2). (2006) 
[97] Incikabi, L., ve Kacar, A.. Analyzing Prospective Mathematics Teachers' Development of Teaching Practices in Mathematics: A Lesson Study Approach. In Handbook of Research on Learner-Centered Pedagogy in Teacher Education and Professional Development (pp. 206-225). IGI Global. (2017)

[98] TALIS. Creating effective teaching and learning environments: First results from TALIS. Paris: OECD Publications. (2009). https://www.oecd.org/berlin/43541636.pdf (Erişim Tarihi:24/06/2021)

[99] Aslan, B.. A comparative study on the teaching profession in Turkey and South Korea: Secondary analysis of TALIS 2008 data in relation to teacher self efficacy. Eurasian Journal of Educational Research, 61, 1-22. (2015)

[100] Bjuland, R., ve Mosvold, R. Lesson study in teacher education: Learning from a challenging case. Teaching and Teacher education, 52, 83-90. (2015)

[101] Stigler, J., ve Hiebert, J. The teaching gap: Best ideas from the world's teachers for improving education in the classroom. New York, NY: Free Press/Simon \& Schuster (Updated 2009). (1999).

[102] Bartalo, D. B. Closing the teaching gap: Coaching for instructional 1 eaders. Corwin Press. (2012) 
EK 1 Portfolyo değerlendirme için kullanılan rubrik

(Burke, Fogarty, Belgrad, 2002, p.186 aktaran; ACAR, E. 2014, (sf. 229-251)

Öğrenci:

Konu:

Tarih:

Amaç / Standart:

\begin{tabular}{|c|c|c|c|c|c|c|}
\hline Ölçüt & Belirleyiciler & 4 & 3 & 2 & 1 & Puan \\
\hline Şekil & $\begin{array}{l}\text {-Yazılış } \\
\text { - Gramer } \\
\text {-Cümle yapısı }\end{array}$ & $\begin{array}{l}0 \text { hata ve üst } \\
\text { düzey yazım }\end{array}$ & 0 hata & 1-2 hata & 2-3 hata & $-x 3=$ \\
\hline $\begin{array}{l}\text { Görsel } \\
\text { çekicilik }\end{array}$ & $\begin{array}{l}\text { •Kapak } \\
\text { •Eser } \\
\text { • Grafikler- } \\
\text { çizimler }\end{array}$ & $\begin{array}{l}\text { Üç ögenin de } \\
\text { yaratıc1 ve } \\
\text { görsel olması }\end{array}$ & $\begin{array}{l}\text { Belirleyici } \\
\text { üç ögeyi de } \\
\text { içermesi }\end{array}$ & $\begin{array}{l}\text { Bir } \\
\text { düşüncenin } \\
\text { eksikliği }\end{array}$ & $\begin{array}{l}\text { İki } \\
\text { düşüncenin } \\
\text { eksikliği }\end{array}$ & $--x 4=$ \\
\hline Düzenleme & $\begin{array}{l}\text { •Bütünlük } \\
\text { •Zaman } \\
\text { çizelgesi } \\
\text { •İçindekiler } \\
\text { listesi }\end{array}$ & $\begin{array}{l}\text { Üç ögenin de } \\
\text { üst düzey bir } \\
\text { organizasyonu } \\
\text { göstermesi }\end{array}$ & $\begin{array}{l}\text { Belirleyici } \\
\text { üç ögeyi de } \\
\text { içermesi }\end{array}$ & $\begin{array}{l}\text { Bir } \\
\text { düşüncenin } \\
\text { eksikliği }\end{array}$ & $\begin{array}{l}\text { İki } \\
\text { düşüncenin } \\
\text { eksikliği }\end{array}$ & $--x 5=$ \\
\hline $\begin{array}{l}\text { Ana } \\
\text { kavramlar } \\
\text { bilgisi }\end{array}$ & $\begin{array}{l}\text {-Ana kavramlar } \\
\text {-Bu } \\
\text { kavramların } \\
\text { anlaşıldığının } \\
\text { göstergesi } \\
\text { çalışmalar } \\
\text {-Uygulama }\end{array}$ & $\begin{array}{l}\text {-Bilgiyi yeni } \\
\text { durumlara } \\
\text { uyarlayabilme } \\
\text { yeteneğini } \\
\text { göstermesi }\end{array}$ & $\begin{array}{l}\text { •Ana } \\
\text { kavramların } \\
\text { üst düzeyde } \\
\text { anlaşı1dığını } \\
\text { göstermesi }\end{array}$ & $\begin{array}{l}\text { •Ana } \\
\text { kavramların } \\
\text { temel } \\
\text { düzeyde } \\
\text { anlaşıldığını } \\
\text { göstermesi }\end{array}$ & $\begin{array}{l}\text { •Portfolyodaki } \\
\text { ana } \\
\text { kavramların } \\
\text { anlaşıldığını } \\
\text { az oranda } \\
\text { göstermesi }\end{array}$ & $--x 6=$ \\
\hline Düşünceler & $\begin{array}{l}\text { •Her bir } \\
\text { çalışma için } \\
\text { •Düşüncelerin } \\
\text { derinliği } \\
\text { •Bireysel } \\
\text { değerlendirme }\end{array}$ & $\begin{array}{l}\text {-Anlayabilme } \\
\text { ve bireysel } \\
\text { değerlendirme } \\
\text { yeteneğini } \\
\text { yansitan } \\
\text { düşünceler }\end{array}$ & $\begin{array}{l}\text { •Her bir } \\
\text { çalışmada } \\
\text { kavramanın } \\
\text { güçlü } \\
\text { olduğunu } \\
\text { gösteren } \\
\text { düşünceler }\end{array}$ & $\begin{array}{l}\text { Büşüncenin } \\
\text { eksikliği }\end{array}$ & $\begin{array}{l}\text {-İki ya da daha } \\
\text { fazla } \\
\text { düşüncenin } \\
\text { eksikliği }\end{array}$ & $--x 7=$ \\
\hline
\end{tabular}

Yorumlar:

Ölçek

Final puan1:--------

$\mathrm{A}=$------

$\mathrm{B}=------$

$\mathrm{C}=--\cdot---$

$\mathrm{D}=$

Final notu :----- 